Research Article

\title{
Transport of As (III) from Acidic Feed Solution through Supported Liquid Membrane Impregnated with Tri-n-dodecylamine and Recovery as As (V)
}

\author{
Najeeb Ullah (iD) $^{1}$ and Gul Akhthar ${ }^{2}$ \\ ${ }^{1}$ US Pakistan Center for Advanced Studies in Energy, University of Engineering and Technology, Peshawar, Pakistan \\ ${ }^{2}$ Institute of Chemical Sciences, University of Peshawar, Peshawar 25120, Khyber Pakhtunkhwa, Pakistan \\ Correspondence should be addressed to Najeeb Ullah; nullah210@gmail.com
}

Received 10 September 2019; Revised 26 February 2020; Accepted 10 March 2020; Published 22 May 2020

Academic Editor: Hakan Arslan

Copyright (c) 2020 Najeeb Ullah and Gul Akhthar. This is an open access article distributed under the Creative Commons Attribution License, which permits unrestricted use, distribution, and reproduction in any medium, provided the original work is properly cited.

\begin{abstract}
The transport of As (III) via supported liquid membrane containing tri-n-dodecylamine (TDDA) as carrier in acidic medium has been studied. Various factors affecting the transport of As (III) were evaluated. The effects of acid concentration $(\mathrm{HCl})$, metal ion concentration, carrier, and strippant $(\mathrm{NaOH})$ concentration on transport of As (III) were thoroughly examined. Mathematical transport model was presented considering the formation of complex between TDDA, acid, and As (III) at feed membrane interface, then the diffusion of this complex through membrane, and finally dissociation of the complex in basic medium at strip membrane interface. The predicted results of this model strongly agree with experimental ones. The stoichiometry of complex was determined on the basis of slope analysis of plots. The mechanism of transport was determined by coupled co-ion transport mechanism, with $\mathrm{H}^{+}$and $\mathrm{Cl}^{-}$coupled ions. The optimized SLM was efficiently used for transport of As (III) from acidic feed solution into basic strippant $\mathrm{NaOH}$ and oxidized to less toxic form As (V) by adding $\mathrm{H}_{2} \mathrm{O}_{2}$.
\end{abstract}

\section{Introduction}

Arsenic is widely distributed element on the Earth crust generally as arsenic sulfide or as metal arsenates [1]. Arsenic is a toxic metal and occurs in the nature in various oxidation states like As (V), As (III), As (0), and As (-III). The hazardous effect is mainly related to its oxidation state. Arsenate As (V) and arsenite As (III) are the prominent form of inorganic arsenic in marine ecosystem, in which As (III) is more toxic. Chronic arsenic exposure is associated with many human health conditions, including skin lesions and cancers of the liver, lung, bladder, and skin. It is also associated with many noncancer health conditions, such as adverse reproductive outcomes, neurological disorders, and impaired cognitive development in children. Cardiovascular effects in human drinking arsenic-contaminated water include black foot disease, atherosclerosis, and cerebrovascular and ischemic heart disease. Exposure to arsenic through ground water has been a major public health problem in the USA, Canada, Mexico, Chile, Argentina, Hungary, Poland, China, Bangladesh, New Zealand, Japan, India, Taiwan, and Italy [2, 3].

Considering the toxic nature of arsenic, it is necessary to remove it from ecosystem and convert it into less toxic form As (V). Different techniques have been used for extraction of arsenic such as adsorption $[4,5]$, precipitation $[6,7]$, and solvent extraction [8]. All these conventional techniques have usually low extraction capability, time consuming, high capital and operating cost, and generation of secondary pollution problems. Among the new efficient methods for extraction of metal ions is supported liquid membrane. The technique comprises the applications of solvent extraction (high selectivity and distribution coefficient) at the same time enabling overcoming typical extraction's drawbacks (loss of carrier due to emulsification and dispersion $[9,10])$. 
A considerable amount of work has been done for extraction of arsenic through liquid membrane using various organic carriers. Perez et al. [11] studied the transport of As (V) through supported liquid membrane, using trioctylphosphine oxide as a mobile carrier and $\mathrm{Na}_{2} \mathrm{SO}_{4}$ as a stripping agent. The recovery of $94 \%$ of As (V) was observed at optimal experimental conditions. Prapasawat et al. [12] separated As (III) and As (V) ions from sulfate feed solution via hollow fiber supported liquid membrane using Cyanex 923 as an extractant, with water as a stripping agent. The results showed that As (V) can be easily transported than As (III). Lothongkum et al. [13] reported the separation of mercury (II) and arsenic (III) from chloride media through hollow fiber supported liquid membrane with tri-n-octylamine as an extractant. It has been observed that extraction and recovery of mercury (II) and arsenic (III) were dependent upon the hydrochloric acid concentration in feed solution, carrier concentration, and strippant concentration. Kiani and Mousavi [14] used emulsion liquid membrane for extraction of As (V). The effect of various contributing factors like stirring speed, concentration of sulfuric acid in the external aqueous phase, concentration of sodium sulfate in the internal stripping phase, and the concentration of carrier in the membrane phase on the extraction efficiency of As (V) has been studied. Mafu et al. [15] observed the extraction of arsenic from real waste water using Aliquat 336 as a mobile carrier in liquid membrane and sodium hydroxide as a strippant. Approximately $98 \%$ arsenic was separated at optimum experimental conditions. Li et al. [16] examined the extraction of As (III) and As (V) across emulsion liquid membrane consisting of succinimide derivative (L113A) with $\mathrm{HCl}$ solution acting as the external phase. The effect of various parameters on the recovery arsenic was studied. More than $93.5 \%$ arsenic was recovered at optimal experimental conditions.

In our previous work, authors have successfully transported $\mathrm{Ag}^{+}$and $\mathrm{Tl}^{3+}[17,18]$ using various supported liquid membranes. This work is mainly focused on extraction of As (III) from liquid medium which is extremely hazardous and its removal is one of the challenges for third-world countries. After extraction of As (III) in stripping solution, it is then converted into less toxic As (V) for safe disposal. The oxidation of As (III) to As (V) was performed by addition of $\mathrm{H}_{2} \mathrm{O}_{2}$. The strippant $\mathrm{NaOH}$ has been envisaged to be involved in dissociating the complex and also providing basic medium for oxidizing As (III) to As (V). During this study, the possible transport mechanism, stoichiometry of chemical reaction during extraction, and the formation of various species during transport were also studied. Furthermore, the effect of various factors like acid concentration in feed solution, carrier concentration in membrane phase, and stripping phase concentration on transport study was first evaluated and then optimized for maximum recovery of arsenic.

1.1. Theoretical. The supported liquid membrane is synthesized by mixing an organic carrier tri-n-dodecylamine by dissolving in xylene and then supported in micro pores of polypropylene film. The resultant composition becomes hydrophobic in nature. The As (III) which is hydrophilic in nature cannot enter directly into hydrophobic liquid organic phase.

The $\mathrm{HCl}$ in aqueous feed solution is dissociated as follows:

$$
\mathrm{HCl}+\mathrm{H}_{2} \mathrm{O} \rightleftharpoons \mathrm{H}_{3} \mathrm{O}^{+}+\mathrm{Cl}^{-}
$$

The organic carrier tri-n-dodecylamine (basic in nature due to lone pair of electron on N) may be represented as $\mathrm{L}$ and is protonated by $\mathrm{H}+$ of the acid as $\mathrm{LH}^{+}$at feed membrane interface:

$$
\mathrm{L}+\mathrm{H}^{+} \rightleftharpoons \mathrm{LH}^{+}
$$

$\mathrm{AsCl}_{3}$ in acid feed solution is converted to metal anionic complex $\mathrm{AsCl}_{4}{ }^{-}$[19]. During transport, the metal must exist in anion complex form [20]:

$$
\mathrm{AsCl}_{3(\mathrm{aq})}+\mathrm{nCl}_{(\mathrm{aq})}^{-} \longrightarrow\left[\mathrm{As}(\mathrm{Cl})_{\mathrm{n}}\right]_{(\mathrm{aq})}^{-\mathrm{n}+3}
$$

The cationic $\left(\mathrm{LH}^{+}\right)$(org) and anionic species $\left[\mathrm{As}(\mathrm{Cl})_{\mathrm{n}}\right]^{-\mathrm{n}+3}$ (aq) then react at feed membrane interface and form the neutral complex as follows:

$$
\mathrm{nLH}_{(\mathrm{org})}^{+}+\left[\mathrm{As}(\mathrm{Cl})_{\mathrm{n}}\right]_{(\mathrm{aq})}^{-\mathrm{n}+3} \rightleftharpoons\left[(\mathrm{LH})_{\mathrm{n}} \cdot \mathrm{As}(\mathrm{Cl})_{\mathrm{n}}\right]_{(\mathrm{org})}
$$

In $\left[\mathrm{As}(\mathrm{Cl})_{\mathrm{n}}\right]^{-\mathrm{n}+3}, \mathrm{n}$ in the subscript are the number of chloride and must be $\geq 4$ while $\mathrm{n}$ in $\mathrm{nLH}^{+}$are the number of protonated TDDA to neutralize the charge created on complex $\left[\mathrm{As}(\mathrm{Cl})_{\mathrm{n}}\right]^{-\mathrm{n}+3}$ by changing the number of chloride ions. The subscript org represents organic phase while aq represents aqueous phase.

The complex $(\mathrm{LH})_{\mathrm{n}} \cdot \mathrm{As}\left(\mathrm{Cl}_{3}\right)_{\mathrm{n}}$ formed at feed membrane interface is extractable into liquid organic phase and diffuses from feed membrane interface to strip membrane interface. The complex at strip membrane interface is dissociated due to $\mathrm{NaOH}$ in the stripping phase as follows:

$$
\begin{aligned}
(\mathrm{LH})_{\mathrm{n}} \cdot \mathrm{As}\left(\mathrm{Cl}_{3}\right)_{\mathrm{n}}+\mathrm{nNaOH} \longrightarrow & \mathrm{As}^{3+}+\mathrm{nH}_{2} \mathrm{O}+\mathrm{nCl}^{-} \\
& +\mathrm{nNa}^{+}+\mathrm{nL}
\end{aligned}
$$

After dissociation of the complex at strip membrane interface, the free carrier molecule (L) is available for another cycle and thus diffuses backward via liquid membrane phase towards feed membrane interface and again forms the complex. This cycle is repeated, until most of the As (III) from feed phase is transported to strippant phase. Figure 1 schematically shows the transport of As (III) through supported liquid membrane. The transport mechanism is of cotransport in which As (III) and co-ion is carried out in the same direction.

At $0.63 \mathrm{~mol} / \mathrm{dm}^{3}$ of TDDA, most of the arsenic (III) is transported to strip phase. The equilibrium constant $K_{\mathrm{As}}$ of (4) for As (III) can be expressed as follows:

$$
\mathrm{kAs}=\frac{\left[(\mathrm{LH})_{\mathrm{n}} \cdot \mathrm{As}\left(\mathrm{Cl}_{3}\right)_{\mathrm{n}}\right]_{\mathrm{org}}}{[\mathrm{L}]_{\mathrm{org} .}^{\mathrm{n}}\left[\mathrm{H}^{+}\right]_{\mathrm{aq}}^{\mathrm{n}}\left[\mathrm{As}^{3+}\right]_{\mathrm{aq}}\left[\mathrm{Cl}^{-}\right]_{\mathrm{aq}}^{\mathrm{n}}}
$$

The distribution coefficient $\lambda_{A s}$ expresses the distribution of As (III) between the liquid membrane and aqueous phases as 


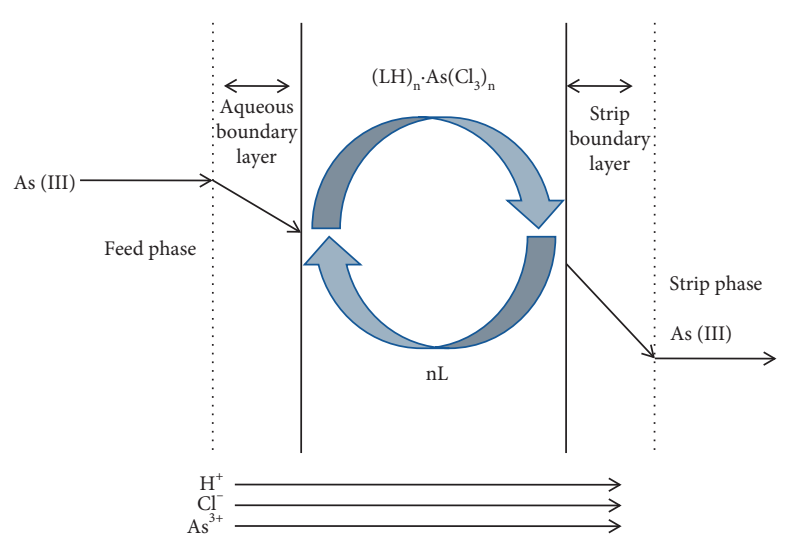

FIGURE 1: Schematic representation of As (III) transport.

$$
\begin{aligned}
\lambda_{\mathrm{As}} & =\frac{\left[(\mathrm{LH})_{\mathrm{n}} \cdot \mathrm{As}\left(\mathrm{Cl}_{3}\right)_{\mathrm{n}}\right]_{\mathrm{org}}}{\left[\mathrm{As}^{3+}\right] \mathrm{aq}} \\
k_{\mathrm{As}} & =\frac{\lambda_{\mathrm{As}}}{[\mathrm{L}]_{\mathrm{org}}^{\mathrm{n}}\left[\mathrm{H}^{+}\right]_{\mathrm{aq}}^{\mathrm{n}}\left[\mathrm{Cl}^{-}\right]_{\mathrm{aq}}^{\mathrm{n}}}
\end{aligned}
$$

and on rearranging of (8),

$$
\lambda_{\mathrm{As}}=\mathrm{k}_{\mathrm{As}}[\mathrm{L}]_{\mathrm{org} .}^{\mathrm{n}}\left[\mathrm{H}^{+}\right]_{\mathrm{aq} .}^{\mathrm{n}}\left[\mathrm{Cl}^{-}\right]_{\mathrm{aq}}^{\mathrm{n}} \text {. }
$$

Now based on the theory and the equations previously described by Rehman et al. [21], consider the extraction constant, distribution coefficient, and laws of diffusion following the same path as can be indicated as follows:

$$
\begin{aligned}
\log \mathrm{J} \eta & =\frac{\log \mathrm{y}+\log \mathrm{T}+\mathrm{n} \log [\mathrm{L}]_{\mathrm{org}}+\mathrm{nlog}\left[\mathrm{H}^{+}\right]_{\mathrm{aq}}+\mathrm{nlog}\left[\mathrm{Cl}^{-}\right]_{\mathrm{aq}}+\log \mathrm{C}_{\mathrm{f}}}{l} \\
\log \mathrm{J} \eta & =\text { constant }+\operatorname{nlog}[\mathrm{L}]_{\mathrm{org}}+\operatorname{nlog}\left[\mathrm{H}^{+}\right]_{\mathrm{aq}}+\mathrm{n} \log \left[\mathrm{Cl}^{-}\right]_{\mathrm{aq}}+\log \mathrm{C}_{\mathrm{f}}
\end{aligned}
$$

The above equation (11) can be used for the stoichiometry of the complex formed at the feed membrane interface. This can be calculated by various means: one way is to keep $\mathrm{T},\left[\mathrm{Cl}^{-}\right],[\mathrm{L}]$, and $\mathrm{C}_{\mathrm{f}}$ constant in (11) and plotting $\log$ $\mathrm{J} \eta \mathrm{Vs} \log \left[\mathrm{H}^{+}\right]$, and the slope of the curve will give the " $\mathrm{n}$ " value for number of $\mathrm{H}^{+}$ions in complex. Similarly, by plotting $\log \mathrm{J} \eta$ versus $\log [\mathrm{L}]$, the slope of plot will give number of moles ( $\mathrm{n}$ ) of TDDA contributing in complex formation of As (III). After transport of arsenite into stripping phase, it is then oxidized to arsenate by addition of $\mathrm{H}_{2} \mathrm{O}_{2}$. The feasible oxidizing conditions for arsenate are as follows.

$\mathrm{HAsO}_{4}{ }^{-}$at $\mathrm{pH} 7 \sim 11$ and $\mathrm{AsO}_{4}{ }^{3-}$ at $\mathrm{pH} 12 \sim 14[1,22]$. $\mathrm{NaOH}$, the strippant, was responsible for providing the basic medium for this reaction.

The oxidation of As (III) with $\mathrm{H}_{2} \mathrm{O}_{2}$ can be described as [23] follows:

$$
\begin{gathered}
\mathrm{As}(\mathrm{OH})_{3}+\mathrm{H}_{2} \mathrm{O}_{2} \longrightarrow \mathrm{HAsO}_{4}^{2-}+2^{\mathrm{H}+}+\mathrm{H}_{2} \mathrm{O} \\
\mathrm{AsO}(\mathrm{OH})_{2}^{-}+\mathrm{H}_{2} \mathrm{O}_{2} \longrightarrow \mathrm{HAsO}_{4}^{2-}+\mathrm{H}^{+}+\mathrm{H}_{2} \mathrm{O}
\end{gathered}
$$

\section{Materials and Methods}

2.1. Chemicals and Reagents. Analytical grade chemicals, $\mathrm{AsCl}_{3}$ of purity $99.99 \%, \mathrm{NaOH}$ of purity $99 \%$, organic carrier
TDDA of purity $\geq 95 \%$, xylene $(99.5 \%$ ), and $\mathrm{HCl}$ of purity $37 \%$ were purchased from Merck. Double distilled deionized water was used in all the experiments. All other chemicals used were of analytical or better grade.

2.2. Analytical Instruments. For determination of metal ion concentration in feed and strip solutions, atomic absorption spectroscopy technique (AAS) of Perkin Elmer model 400 was used. For measurement of $\mathrm{pH}$, the $\mathrm{pH}$ meter of Metrohm model 827 was used. For viscosity measurement of various concentration of TDDA in xylene viscometer/rheometer of Brookfield LVDV-III was used.

2.3. Permeation Cell. The transport experiments of metal ion were carried out in two-compartment cell made of Perspex material as indicated in our previous study [18]. The volume capacity of each half cell of compartment had $250 \mathrm{~cm}^{3}$ and effective membrane area was $23.79 \mathrm{~cm}^{2}$. Each half cell was equipped with sampling port, synchronous motors, and $\mathrm{pH}$ electrode. The stirring speed of $1500 \mathrm{rpm}$ [17] has already optimized for like permeation cell and carrier, so this stirring speed was used in all the transport study. All the experiments were performed at $25 \pm 0.5^{\circ} \mathrm{C}$. All the experiments were run in triplicate. 
2.4. SLM Preparation and Transport Study. Celgard 2400 microporous polypropylene thin film (Hoechst Celanese USA) was used as a solid support for liquid organic carrier. The microporous polypropylene thin film ( $25 \mu \mathrm{m}$ thickness) was having pore size of $0.02 \mu \mathrm{m}$ and porosity of $38 \%$. $8 \times 6 \mathrm{~cm}$ rectangular pieces were prepared by cutting the polypropylene film. These pieces were soaked in predetermined concentration of TDDA in Petri dish for overnight. The excess amount of TDDA and other organic solvents were taken out by draining off the membrane for five minutes.

The membrane after impregnation with TDDA was tightly fixed between the two half cells of the compartment cell (the feed phase and the strippant phase). The two half cells were filled with $250 \mathrm{~mL}$ of predetermined concentration of feed and strip solutions. The solution was continuously stirred to overcome concentration polarization at the interfaces of feed and strip. Samples were taken after regular time interval from both feed and strip solutions and analyzed for metal ion concentration. The flux (J) was calculated as in our previous study [17].

\section{Results and Discussion}

3.1. Effect of Carrier Concentration. To evaluate the effect of carrier concentration on transport of As (III), various concentration of organic carrier (TDDA) ranging from $0.1261 \mathrm{~mol} / \mathrm{dm}^{3}$ to $1.1349 \mathrm{~mol} / \mathrm{dm}^{3}$ was used, while keeping the concentration of $\mathrm{HCl}$ at $0.75 \mathrm{~mol} / \mathrm{dm}^{3}$ and $\mathrm{NaOH}$ at $1.05 \mathrm{~mol} / \mathrm{dm}^{3}$. The variation in flux of As (III) due to carrier concentration is shown in Figure 2. This figure shows that maximum flux of As (III) is obtained at $0.63 \mathrm{~mol} / \mathrm{dm}^{3}$ of TDDA and beyond this concentration the extraction decreases. The maximum transport of As (III) at $0.63 \mathrm{~mol} / \mathrm{dm}^{3}$ of TDDA is as per proposed (2) and (4). More numbers of TDDA interact with $\mathrm{H}^{+}$by increasing the concentration of TDDA (L) and form $\mathrm{LH}^{+}$, which on further reaction with $\left[\mathrm{As}\left(\mathrm{Cl}_{3}\right)_{\mathrm{n}}\right]^{\mathrm{n}-}$ increases the concentration of complex $(\mathrm{LH})_{\mathrm{n}} \cdot \mathrm{As}\left(\mathrm{Cl}_{3}\right)_{\mathrm{n}}$ and thus eventually increases the transport of As (III). The decrease in transport beyond $0.63 \mathrm{~mol} / \mathrm{dm}^{3}$ may be due to high viscosity of liquid membrane [21]. As maximum transport of As (III) is achieved at $0.63 \mathrm{~mol} / \mathrm{dm}^{3}$ of TDDA, hence it was considered the optimum concentration for further study to optimize other parameters.

For determination of the number of carrier molecules involved in the complex formation, (11) was used by plotting $\log [$ TDDA] versus $\log \mathrm{J} \eta$ (Figure 3), keeping temperature and $\mathrm{HCl}$ concentration constant in feed solution. The slope calculated of the plot is approximately 1 , which indicates that one molecule of TDDA is involved in the transport of As (III) as well as in the complex formation.

3.2. Effect of HCl Concentration. To study the effect of acid concentration in feed solution on transport of As (III), various concentrations of $\mathrm{HCl}$ ranging from $0.25 \mathrm{~mol} / \mathrm{dm}^{3}$ to $0.95 \mathrm{~mol} / \mathrm{dm}^{3}$ were used, while keeping the concentration of carrier and strip phase $(\mathrm{NaOH})$ constant at $0.63 \mathrm{~mol} / \mathrm{dm}^{3}$ and $1.05 \mathrm{~mol} / \mathrm{dm}^{3}$, respectively. Figure 4 indicates that as the



FIGURE 2: Effect of carrier concentration on transport of As (III). $[\mathrm{HCl}]$ in feed solution $=0.75 \mathrm{~mol} / \mathrm{dm}^{3},[$ TDDA] in membrane phase $=0.1261 \mathrm{~mol} / \mathrm{dm}^{3}$ to $1.1349 \mathrm{~mol} / \mathrm{dm}^{3},[\mathrm{NaOH}]$ in stripping solution $=1.05 \mathrm{~mol} / \mathrm{dm}^{3}, \quad[$ As $\quad$ (III) $]=8.6019 \times 10^{-4} \mathrm{~mol} / \mathrm{dm}^{3}$, $\left[\mathrm{H}_{2} \mathrm{O}_{2}\right]=10^{-7} \mathrm{~mol} / \mathrm{L}$, time $=4.0 \mathrm{~h}$.

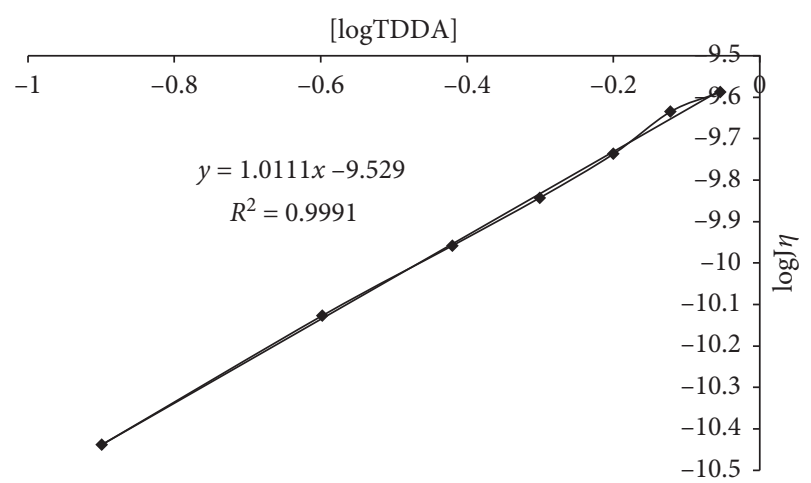

FIGURE 3: Plot of $\log$ [TDDA] versus $\log \mathrm{J} \eta$ (the same operating conditions as given in Figure 2).

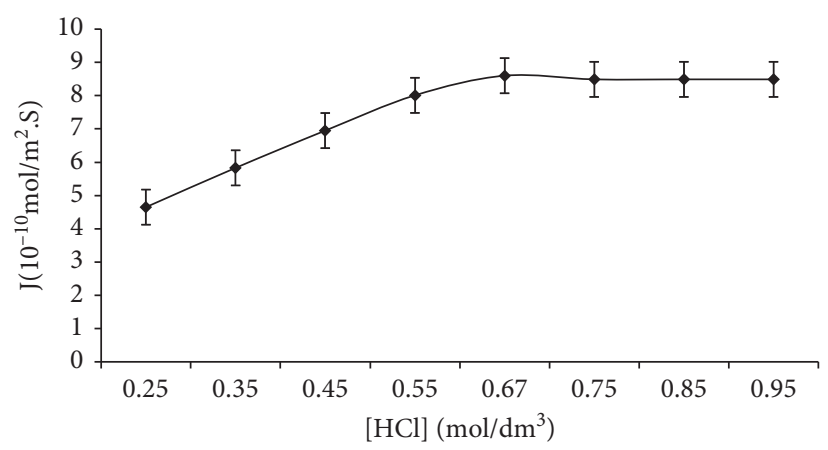

FIgURE 4: Effect of $\mathrm{HCl}$ concentration on transport of As (III). $[\mathrm{HCl}]$ in feed solution $=0.25 \mathrm{~mol} / \mathrm{dm}^{3}$ to $0.95 \mathrm{~mol} / \mathrm{dm}^{3}$, [TDDA] in membrane phase $=0.63 \mathrm{~mol} / \mathrm{dm}^{3}, \quad[\mathrm{NaOH}]$ in stripping solution $=1.05 \mathrm{~mol} / \mathrm{dm}^{3}$, $[$ As (III) $]=8.6019 \times 10^{-4} \mathrm{~mol} / \mathrm{dm}^{3},\left[\mathrm{H}_{2} \mathrm{O}_{2}\right]=$ $10^{-7} \mathrm{~mol} / \mathrm{L}$, time $=4.0 \mathrm{~h}$.

concentration of $\mathrm{HCl}$ increases, the extraction of As (III) also increases and maximum flux of As (III) is achieved at $0.67 \mathrm{~mol} / \mathrm{dm}^{3}$ of $\mathrm{HCl}$. This increase in extraction of As (III) is in favor of proposed (4), as by increasing acid concentration, more $\mathrm{H}^{+}$and $\mathrm{Cl}^{-}$interact with carrier molecule and enhance the complex formation. However, by further increasing the 
$\mathrm{HCl}$ concentration beyond $0.67 \mathrm{~mol} / \mathrm{dm}^{3}$, the transport of As (III) decreases. The decrease in extraction of metal ions by SLM due to increase in acid concentration has been reported by some authors $[18,20]$ due to excessive amount of $\mathrm{H}^{+}$and $\mathrm{Cl}^{-}$in feed solution and forms the adduct complex $\mathrm{H}_{\mathrm{n}} \mathrm{AsCl}_{\mathrm{n}+3}$. Hence, for this transport, $0.67 \mathrm{~mol} / \mathrm{dm}^{3}$ of $\mathrm{HCl}$ was considered the optimum concentration to optimize subsequent parameters affecting transport of As (III).

To determine the amount of hydrogen taking part in the stoichiometry of complex, (11) was used by plotting log $[\mathrm{HCl}]$ versus $\log \mathrm{J} \eta$ (Figure 5) by keeping carrier concentration in membrane phase and temperature constant. Slope of the curve calculated is round about 1 that shows one $\mathrm{H}^{+}$ takes part in the complex formation. These slopes values "one" from Figures 3 and 1 confirm the formation of $1: 1$ complex between metal carrier and acid.

As the transport study concluded that one molecule of TDDA and $\mathrm{H}^{+}$is involved in the complex formation of As (III), hence the complex formed during this extraction study may be $\mathrm{LH} . \mathrm{AsCl}_{\mathrm{n}}$ (this confirms that the " $\mathrm{n}$ " no. of chlorides in $\mathrm{AsCl}_{n}$ is four).

3.3. Effect of Strip Phase Concentration. The strippant has dual function. Firstly, the stripper performs significant role in transport of As (III), because it dissociates the complex at strip membrane interface and releases As (III) in strip solution as per (5). Secondly, $\mathrm{NaOH}$ provide the basic medium for the oxidation of As (III) to As (V). To investigate the effect of $\mathrm{NaOH}$ on extraction of As (III), various concentrations of $\mathrm{NaOH}$ ranging from $0.25 \mathrm{~mol} / \mathrm{dm}^{3}$ to $1.50 \mathrm{~mol} /$ $\mathrm{dm}^{3}$ were used, while keeping the TDDA concentration as per optimized conditions at $0.63 \mathrm{~mol} / \mathrm{dm}^{3}$ and $\mathrm{HCl}$ concentration at $0.67 \mathrm{~mol} / \mathrm{dm}^{3}$. Linear relationship was found between the extraction of As (III) and $\mathrm{NaOH}$ concentration as reflected in (Figure 6). The increase in transport of As (III) by increasing the strippant concentration produces more $\mathrm{OH}^{-}$that enhances the dissociation of the complex and liberates more As (III) into strip solution. The maximum extraction of As (III) (99.45\%) was observed at $1.05 \mathrm{~mol} / \mathrm{dm}^{3}$ of $\mathrm{NaOH}$ and on further increasing the extraction becomes constant indicated that no blocking or precipitate formation takes place by increasing strippant concentration as observed in our previous study [17]. The precipitate formation was blocked by adding $\mathrm{H}_{2} \mathrm{O}_{2}$ which oxidizes As(III) to less toxic As (V) and forming soluble complexes $\mathrm{HAsO}_{4}{ }^{2-}$ $[1,22]$.

For conversion of As (III) to As (V), $\mathrm{H}_{2} \mathrm{O}_{2}$ at concentration level of $10^{-7} \mathrm{~mol} / \mathrm{L}$ was added to strip solution [23]. Since the stripping phase consists of $\mathrm{OH}^{-}$, it has been reported that presences of these ions further improve the oxidation of As (III) to As (V) [22].

3.4. Effect of Metal Ion Concentration. To investigate the performance and transport capability of this SLM, various concentrations of As (III) ranging from $2.867 \times 10^{-4} \mathrm{~mol} /$ $\mathrm{dm}^{3}$ to $25.81 \times 10^{-4} \mathrm{~mol} / \mathrm{dm}^{3}$ were used in feed solution and its flux was studied at optimized conditions, i.e., $\mathrm{HCl}$ concentration in feed solution at $0.75 \mathrm{~mol} / \mathrm{dm}^{3}$, TDDA

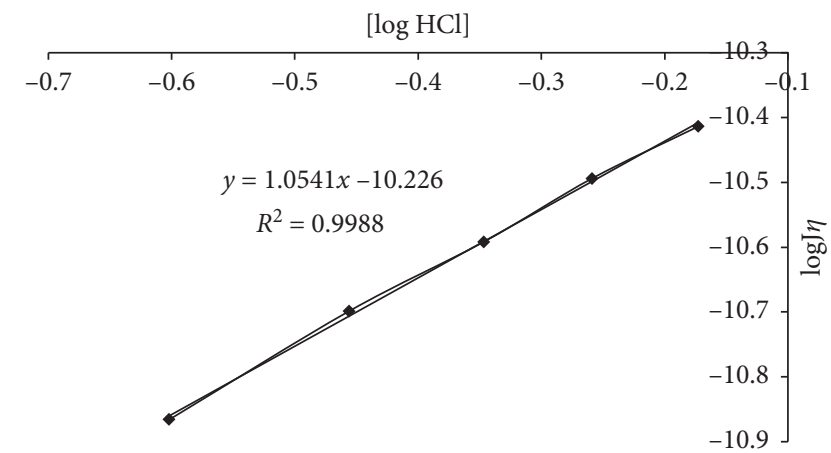

FIgURE 5: Plot of $\log [\mathrm{HCl}]$ versus $\log \mathrm{J} \eta$ (the same operating conditions as given in Figure 4).

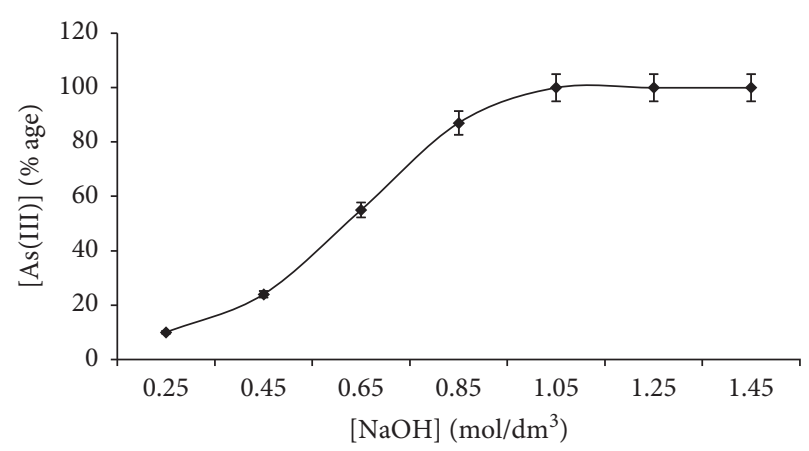

Figure 6: Effect of $\mathrm{NaOH}$ concentration on transport of As (III). $[\mathrm{HCl}]$ in feed solution $=0.67 \mathrm{~mol} / \mathrm{dm}^{3}$, [TDDA] in membrane phase $=0.63 \mathrm{~mol} / \mathrm{dm}^{3},[\mathrm{NaOH}]$ in stripping solution $=0.25 \mathrm{~mol} /$ $\mathrm{dm}^{3}$ to $1.50 \mathrm{~mol} / \mathrm{dm}^{3}$, [As (III) $]=8.6019 \times 10^{-4} \mathrm{~mol} / \mathrm{dm}^{3},\left[\mathrm{H}_{2} \mathrm{O}_{2}\right]=$ $10^{-7} \mathrm{~mol} / \mathrm{L}$, time $=4.0 \mathrm{~h}$.

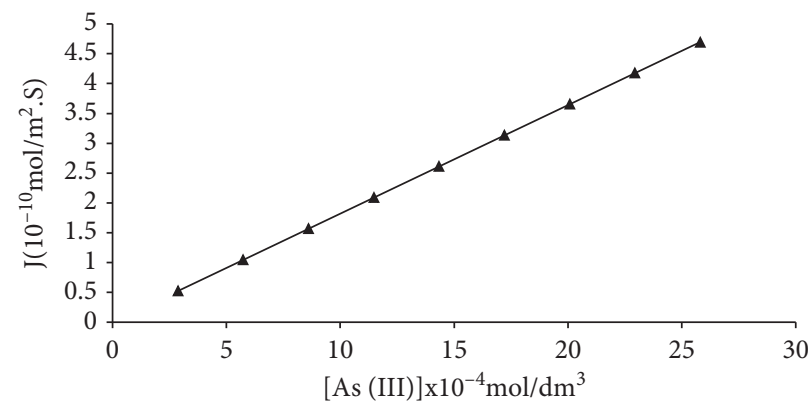

FIGURE 7: Effect of metal ion concentration on transport of As (III). [HCl] in feed solution $=0.75 \mathrm{~mol} / \mathrm{dm}^{3}$, [TDDA] in membrane phase $=0.63 \mathrm{~mol} / \mathrm{dm}^{3},[\mathrm{NaOH}]$ in stripping solution $=1.05 \mathrm{~mol} /$ $\mathrm{dm}^{3}$, [As (III) $]=2.867 \times 10^{-4} \mathrm{~mol} / \mathrm{dm}^{3}$ to $25.8 \times 10^{-4} \mathrm{~mol} / \mathrm{dm}^{3}$, $\left[\mathrm{H}_{2} \mathrm{O}_{2}\right]=10^{-7} \mathrm{~mol} / \mathrm{L}$, time $=4.0 \mathrm{~h}$.

concentration in membrane phase at $0.63 \mathrm{~mol} / \mathrm{dm}^{3}$, and $\mathrm{NaOH}$ concentration at $1.05 \mathrm{~mol} / \mathrm{dm}^{3}$. Figure 7 indicates that as the concentration of As (III) in feed solution increases, the flux also increases from $0.522 \times 10^{-10} \mathrm{~mol} / \mathrm{m}^{2} \mathrm{~s}$ to $4.695 \times 10^{-10} \mathrm{~mol} / \mathrm{m}^{2} \mathrm{~s}$. This increase in flux is in accordance with (11) where flux (J) is directly proportional to feed concentration $\left(\mathrm{C}_{\mathrm{f}}\right)$. This study further illustrates that no 
metal loading of carrier TDDA takes place up to $25.81 \times 10^{-4} \mathrm{~mol} / \mathrm{dm}^{3}$ of As (III) in feed solution.

\section{Conclusions}

The study showed that this SLM can be potentially used for transport, removal, and separation of As (III) from their mixtures, as more than $99 \%$ of As (III) was recovered in strip solution at optimized conditions. Further, it can be converted to less toxic form As (V) by adding oxidant $\mathrm{H}_{2} \mathrm{O}_{2}$. The flux $\mathrm{J}_{\mathrm{As}(\mathrm{III})}$ was increased by increasing carrier concentration up to $0.63 \mathrm{~mol} / \mathrm{dm}^{3}$, and on further increasing the carrier concentration the transport of As (III) was decreased. The flux $\mathrm{J}_{\mathrm{As}(\mathrm{III})}$ was also augmented by increasing $\mathrm{HCl}$ concentration in feed solution up to $0.067 \mathrm{~mol} / \mathrm{dm}^{3}$ and then decreased.

The optimum condition for this SLM was found as follows: TDDA concentration in membrane phase at $0.63 \mathrm{~mol} / \mathrm{dm}^{3}$, $\mathrm{HCl}$ concentration in feed solution at $0.67 \mathrm{~mol} / \mathrm{dm}^{3}$, and $\mathrm{NaOH}$ concentration in strip solution at $1.05 \mathrm{~mol} / \mathrm{dm}^{3}$.

\section{Data Availability}

The data used to support the findings of this study are included within the article.

\section{Conflicts of Interest}

The authors declare that they have no conflicts of interest.

\section{References}

[1] S. Gupta and V. Gupta, "Speciation and toxicity of arsenic: a human carcinogen," Research Journal of Recent Sciences, vol. 2, pp. 45-53, 2013.

[2] M. Tiziana and F. Alberto, "Arsenic removal by liquid membranes," Membranes, vol. 5, pp. 150-167, 2015.

[3] U. Riaz and H. H. Naz, "Arsenic poisoning in Bangladesh," Oman Medical Journal, vol. 26, no. 3, p. 207, 2011.

[4] S. Yao, Z. Liu, and Z. Shi, "Arsenic removal from aqueous solutions by adsorption onto iron oxide/activated carbon magnetic composite," Journal of Environmental Health Science and Engineering, vol. 12, p. 58, 2014.

[5] W. G. Li, X. J. Gong, K. Wang, X. R. Zhang, and W. B. Fan, "Adsorption characteristics of arsenic from micro-polluted water by an innovative coal-based mesoporous activated carbon," Bioresource Technology, vol. 165, pp. 166-173, 2014.

[6] S. Tokunaga, "Removal of arsenic from water," Journal of Japan Society on Water Environment, vol. 20, pp. 452-456, 1997.

[7] M. M. Matlock, B. S. Howerton, and D. A. Atwood, "Chemical precipitation of heavy metals from acid mine drainage," Water Research, vol. 36, no. 19, pp. 4757-4764, 2002.

[8] R. K. Anthony and A. A. Dapaah, "Solvent extraction of arsenic from acid medium using zinc hexamethylene dithiocarbamate as an extractant," Analytica Chimica Acta, vol. 360, pp. 43-52, 1998.

[9] J. D. Gyves and E. R. San-Miguel, "Metal ion separations by supported liquid membranes," Industrial \& Engineering Chemistry Research, vol. 38, pp. 2182-2202, 1999.
[10] C. Y. Feng, K. C. Khulbe, T. Matsuura, and A. F. Ismail, "Recent progresses in polymeric hollow fiber membrane preparation, characterization and applications," Separation and Purification Technology, vol. 111, pp. 43-71, 2013.

[11] M. Perez, J. Reyesaguilera, T. Saucedo, M. Gonzalez, R. Navarro, and M. Avilarodriguez, "Study of as (V) transfer through a supported liquid membrane impregnated with trioctylphosphine oxide (Cyanex 921)," Journal of Membrane Science, vol. 302, pp. 119-126, 2007.

[12] T. Prapasawat, P. Ramakul, C. Satayaprasert, U. Pancharoen, and A. W. Lothongkum, "Separation of As(III) and $\mathrm{As}(\mathrm{V})$ by hollow fiber supported liquid membrane based on the mass transfer theory," Korean Journal of Chemical Engineering, vol. 25, no. 1, pp. 158-163, 2008.

[13] A. W. Lothongkum, S. Suren, S. Chaturabul, N. Thamphiphit, and U. Pancharoen, "Simultaneous removal of arsenic and mercury from natural-gas-co-produced water from the Gulf of Thailand using synergistic extractant via HFSLM," Journal of Membrane Science, vol. 369, no. 1-2, pp. 350-358, 2011.

[14] S. Kiani and S. M. Mousavi, "Ultrasound assisted preparation of water in oil emulsions and their application in arsenic (V) removal from water in an emulsion liquid membrane process," Ultrasonics Sonochemistry, vol. 20, no. 1, pp. 373-377, 2013.

[15] L. D. Mafu, T. A. M. Msagati, and B. B. Mamba, "The simultaneous stripping of arsenic and selenium from wastewaters using hollow-fibre supported liquid membranes," Environmental Monitoring and Assessment, vol. 186, no. 12, pp. 8865-8874, 2014.

[16] L. Li, P. Yan, W. Gao, and Y. Li, "Emulsion liquid membrane separation of As(III) and As(V)," Fresenius' Journal of Analytical Chemistry, vol. 363, no. 3, pp. 317-319, 1999.

[17] S. U. Rehman, G. Akhtar, M. A. Chaudry, K. Ali, and N. Ullah, "Transport of Ag+ through tri-n-dodecylamine supported liquid membranes," Journal of Membrane Science, vol. 389, pp. 287-293, 2012.

[18] S. u. Rehman, G. Akhtar, and M. A. Chaudry, "Coupled transport of $\mathrm{Tl} 3+$ through triethanolamine-xylene-polypropylene supported liquid membranes," Journal of Industrial and Engineering Chemistry, vol. 18, no. 1, pp. 492-498, 2012.

[19] N. N. Greenwood and A. Earnshaw, Chemistry of Elements, pp. 650-665, Pergamon Press, Oxford, UK, 1984.

[20] S. u. Rehman, G. Akhtar, M. A. Chaudry, N. Bukhari, N. Najeebullah, and N. Ali, "Mn (VII) ions transport by triethanolamine cyclohexanone based supported liquid membrane and recovery of $\mathrm{Mn}$ (II) ions from discharged zinc carbon dry battery cell," Journal of Membrane Science, vol. 366, no. 1-2, pp. 125-131, 2011.

[21] S. Rehman, G. Akhtar, and M. A. Chaudry, "Coupled transport of $\mathrm{Pb}^{2+}$ through tri-noctylamine-xylene-polypropylene supported liquid membranes: Can," The Canadian Journal of Chemical Engineering, vol. 91, no. 6, pp. 1140-1152, 2013.

[22] W. T. Zhaohui, R. Bush, A. L. Sullivan, and L. Jianshe, "Simultaneous redox conversion of chromium (VI) and arsenic (III) under acidic conditions," Environmental Science \& Technology, vol. 47, pp. 6486-6492, 2013.

[23] P. Maurizio, C. Luigi, and J. M. Frank, "Arsenite oxidation by $\mathrm{H}_{2} \mathrm{O}_{2}$ in aqueous solutions," Geochimica et Cosmochimica Acta, vol. 63, pp. 2727-2735, 1999. 